\title{
ズワイガニ罐詰肉の成分に就て
}

(昭和七年九月十九日受領 炤和七年十一月甘五日印刷)

波多腰 + ス

\section{A. 緒言}

ズワイカニ (Chionecetes phalangium Tabr.) は京都、福井、石川、富山、新鼬等の各府縣の沿海 に於て冬期間㴡獲せられ其の座額每年的 100 萬 $\mathrm{kg}$ (約 30 萬圆) 飞澾す。普通は湶獲後海水中に

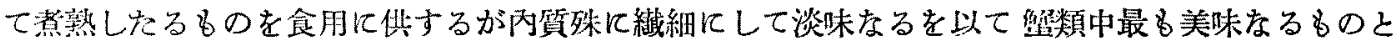

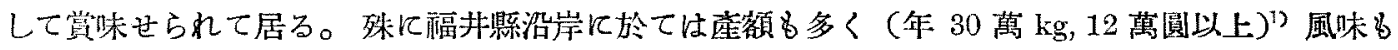

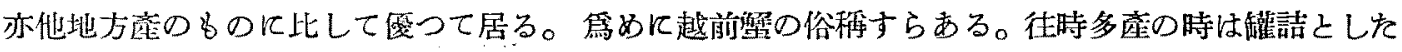
時もあるが現今は專ら劣熟後市場に出でて賞味せられる。私は此の留の䠰詰肉を得るの機會を得た れば其の成分を定量して此の蟹肉に關する食品化學的知識を進め庞いと思ふ。

\section{B. 實 驗 成 綪}

\section{1. 實驗材料}

1930 尔 2 月 5 日、京都府丹後國間人町沿海にて漁獲したズワイガ二家通ちに管津叮の京都府立.

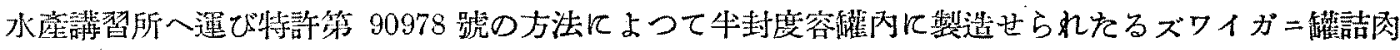

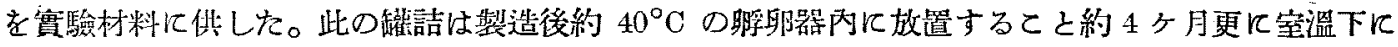

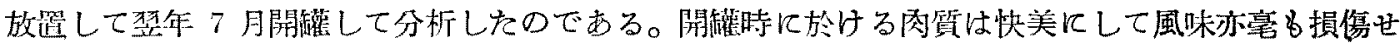
られて居なかつた。

\section{2. 普通成分}

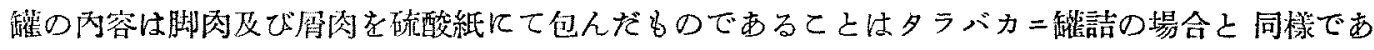

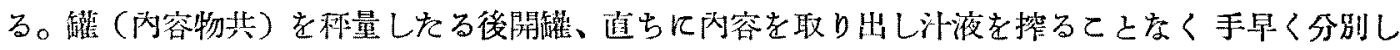
空触、硫酸紙、骨、汒、肉等を夫科量して次の結果を得た。

第 1 表

\begin{tabular}{l|c|c}
\hline No. of Can. & Can I & Can 1 \\
\hline Weight of Can with content & $284 \mathrm{~g}$ & $293 \mathrm{~g}$ \\
Weight of can without content & 64 & 64.5 \\
Weight of content & 250 & 228.5 \\
Wt. of parchment paper & 9 & 7 \\
Wt. of juice & 20.5 & 21 \\
Wt. of bone & 1 & 1.5 \\
Wt. of net edible meat & 189.5 & 199 \\
\hline
\end{tabular}

此の結楽によれば 1 䧾の目方約 $300 \mathrm{~g}$ 内外であつてそのうちの純可食肉量は約 190-200 $\mathrm{g}$ であ る。此の數值は堡工船製造のタラバカ二罐詰の場合とほ山同樣であるがたら゙汁液量は本材料の場合 に於て約 $20 \mathrm{~g}$ であるがタラバ塹詰の場合には約 $30 \mathrm{~g}$ 以上である。 


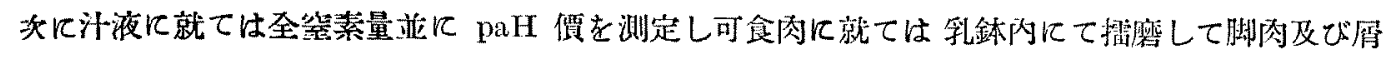
肉をよく混和したる後普通成分を常法に從つて定量した。武中の數值は何れも3 旬行したる實驗 數值の平均值である。就中 glycogen は次の操作によつて定量したのである。先づ可食肉 $30 \mathrm{~g}$ とり之に 60\% KOH-solution $50 \mathrm{cc}$ を扠へて約 2 時間 Water-bath 上にて加溫して glycogen 溶出せしあた。然る後放冾後加水して約 $200 \mathrm{cc}$ とし $95 \%$ Alcohol $200 \mathrm{cc}$ を㞦へて glycogen を

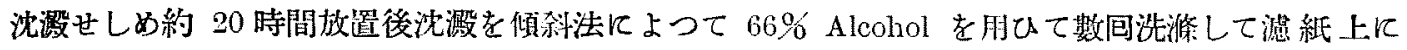
移した。次に此の沈澱 glycogen を溫水に溶解し（約 $200 \mathrm{cc}$ を）之に conc. $\mathrm{HCl} 10 \mathrm{cc}$ を拈 てWater-bath 上にて約 3 時間扠溫して水解後中和して一定容棈 $250 \mathrm{cc}$ とをしその $20 \mathrm{cc}$ 宛とつ て Bertrand 氏法によつて glucose 量を定量しそれに 0.927 を乘じて glycogen の量となしたので ある。

符 2 斐

Content of Juice.

\begin{tabular}{|c|c|c|}
\hline juice $\quad$ No. of Can & Can 1 & Can 2. \\
\hline Amount of juice & $20.5 \mathrm{~g}$ & $21 \mathrm{~g}$ \\
\hline$\%$ of total $N$ & 0.887 & 0.833 \\
\hline $\begin{array}{l}\text { Amount of protein. }(X \times 6.25) \text { in whole } \\
\text { juice }\end{array}$ & 1.14 & 1.22 \\
\hline $\mathrm{paH}$ value of juice & 6.533 & - \\
\hline
\end{tabular}

第 3 表

Composition of net edible meat.

\begin{tabular}{|c|c|c|c|c|}
\hline \multirow[t]{2}{*}{ No. of Can } & \multirow[b]{2}{*}{ Can 1.} & \multirow{2}{*}{ Can 2.} & \multicolumn{2}{|c|}{ Averaged percentage } \\
\hline & & & in fresh meat & $\begin{array}{c}\text { in water free } \\
\text { meat }\end{array}$ \\
\hline Water & 77.90 & 77.65 & 77.78 & - \\
\hline Protein $(N \times 6.25)$ & 1883 & 19.35 & 19.01 & 86.41 \\
\hline Fat & 0.66 & $0.8 \overline{5}$ & 0.76 & 3.45 \\
\hline Glycogen & 0.25 & 0.23 & 0.24 & 1.09 \\
\hline Ash & 2.03 & 1.95 & 1.99 & 9.05 \\
\hline
\end{tabular}

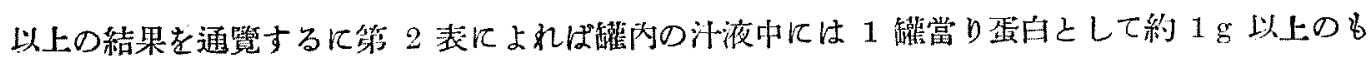
のが溶解して居るととがわかる。又第3 表に上ればズワイカ二肉は約 $78 \%$ の水分を含子固形物

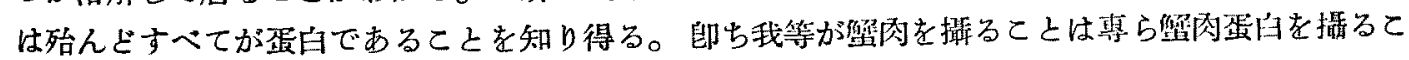
とに外ならないのであつて其の味が他の魚貝肉の昧に比して淡白なのも亦てれに原因するのであら 3 。

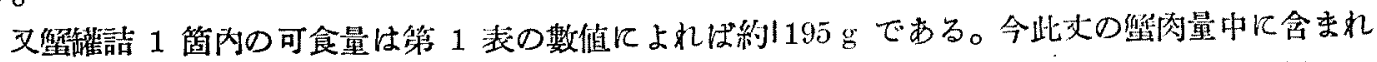

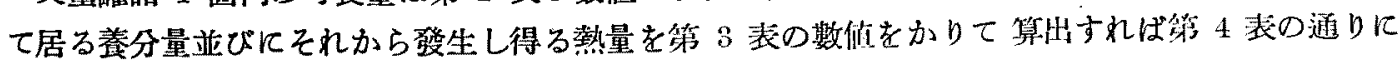
なる。 
第 4 表

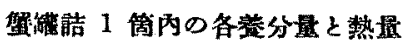

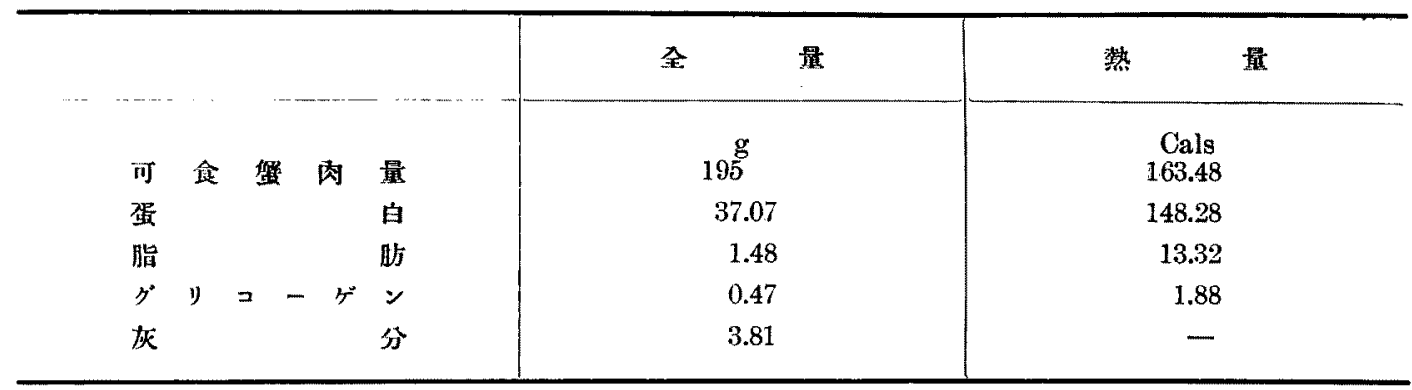

即ち 1 䠰當り 163 Cals. を保有するのであつてその大部分は蛋白によつて与められて居ることは 前記の通りである。

\section{3. 虽肉蛋白中の窒素の形態}

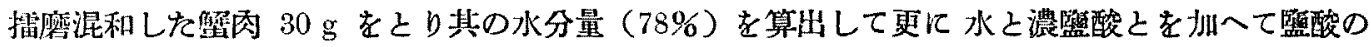
濃度を $20 \%$ にならしめた挠 36 時間州熱水解したる後 Van Slyke 氏法によつて各種形態の䇪素量

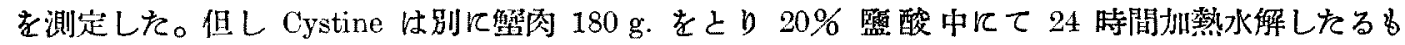
のにつを奥田氏の沃度法”によつて定量したる後其の空素量を算出して表出したのである。

$$
\text { 第 } 5 \text { 表 }
$$

Forms of Nitrogen in net Edible meat

\begin{tabular}{|c|c|c|c|c|c|c|}
\hline & \multicolumn{3}{|c|}{ Experiment 1.} & \multicolumn{3}{|c|}{ Experiment 2.} \\
\hline & $\begin{array}{l}\text { In Origi- } \\
\text { nal meat }\end{array}$ & $\left|\begin{array}{l}\text { In Water } \\
\text { free meat }\end{array}\right|$ & $\begin{array}{l}\text { In the solu- } \\
\text { ble in HCI } \\
\text { Nitrogen }\end{array}$ & $\begin{array}{l}\text { In Origi- } \\
\text { nal meat }\end{array}$ & $\begin{array}{l}\text { In Water } \\
\text { free meat }\end{array}$ & $\begin{array}{l}\text { In the solu- } \\
\text { ble in } \mathrm{HCl} \\
\text { Nitrogen }\end{array}$ \\
\hline & I & II & III & IV & $\mathrm{V}$ & VI \\
\hline Water & $\begin{array}{c}\% \\
77.900\end{array}$ & $\%$ & $\%$ & $\begin{array}{c}\% \\
77.650\end{array}$ & $\%$ & $\%$ \\
\hline $\operatorname{Total}-N$ & 2.999 & 13.57 & & 3.051 & $13.6 \overline{5}$ & \\
\hline Insoluble in $\mathrm{HCl} N$ & 0.024 & 0.11 & & 0.020 & 0.09 & \\
\hline Soluble in $\mathrm{HCl} N$ & 2.975 & 13.46 & 100.00 & 3.031 & 13.56 & 100.00 \\
\hline Ammonia- $N$ & 0.255 & 1.15 & 8.57 & 0.267 & 1.19 & 8.81 \\
\hline Humine- $N$ & 0.041 & 0.19 & 1.38 & 0.026 & 0.11 & 0.86 \\
\hline Total- $N$ in form of bases & 0.860 & 3.89 & 28.91 & 0.859 & 3.84 & 28.34 \\
\hline Amino- $N$ in bases & 0.492 & 2.23 & 16.54 & 0.471 & 2.11 & 15.54 \\
\hline Arginine- $N$ & 0.353 & 1.60 & 11.89 & 0.389 & 1.74 & 12.83 \\
\hline Histidine- $N$ & 0.154 & 0.69 & 5.13 & 0.144 & 0.64 & 4.75 \\
\hline Lysine- $N$ & 0.324 & 1.47 & 10.92 & 0.297 & 1.33 & 9.80 \\
\hline Cystine- $N$ & 0.029 & 0.13 & 0.97 & 0.029 & 0.13 & 0.96 \\
\hline Total- $N$ in filtrate from bases & 1.818 & 8.23 & 61.11 & 1.871 & 8.37 & 61.73 \\
\hline Amino- $N$ in non-bases & 1.782 & 8.06 & 59.90 & 1.805 & 8.08 & 59.55 \\
\hline
\end{tabular}

第 5 表の第 III 行及び第 VI 行によればズワイカ二肉蛋白中には Lysine の含量多く Arginine, Histidine 及び Cystine の含量も相當であることがわかる。

今蟹肉蛋白に就て Diamino acids を定量報告せられたる結果を例記して第 5 表の結果が偶然で ないととの證とする。 
第 6 表

Content of Diamino acids in various crab-meat-proteins

\begin{tabular}{|c|c|c|c|c|c|c|}
\hline \multirow[t]{2}{*}{ Author } & \multicolumn{2}{|c|}{ Sekine ${ }^{3)}$} & \multicolumn{2}{|c|}{ Ogura \& Fujikawa } & \multicolumn{2}{|c|}{ Hatakoshi } \\
\hline & Taraba-crab $\$$ & Taraba-crabz & Taraba-crab & Zuwai-crab\# & Zuwai-crab & Zuwai-crab \\
\hline Arginine & $9 . \%$ & 10.9 & $\%$ & $\%$ & $\begin{array}{c}\% \\
36.94\end{array}$ & $\begin{array}{c}\% \\
39.86\end{array}$ \\
\hline Histidine & 5.78 & 3.62 & - & - & 18.93 & 17.29 \\
\hline Lysine & 7.03 & 7.28 & - & - & 56.94 & 51.10 \\
\hline Cystine & 3.15 & 3.2 & 0.84 & 1.19 & 8.31 & 8.23 \\
\hline
\end{tabular}

借考 以上の5ち筆者のものは第 5 表の数值から换算したもので䧳肉中の全堂素を 100 とした洔の Diamino acids の会量であるが 3) 改で 4) の数值は船肉蛋白に就ての定量結果である。文そのらち Cystine は關根氏 のものは全硫黄の定量值から换算せられたものであるが小念氏及で篗者等のものは奥田氏の沃度法によつたもの である。

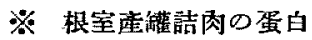

※カムチャッカ座鑊詰肉の盗白

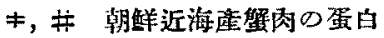

記述する迄もなく此等の Diamino acids は動物の生育のために重要なる役目を果するのですつて

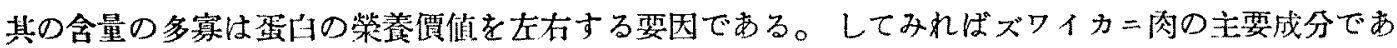

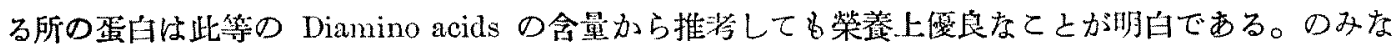

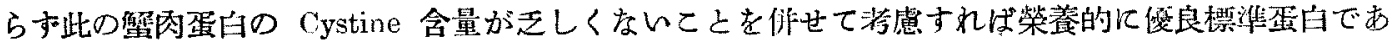

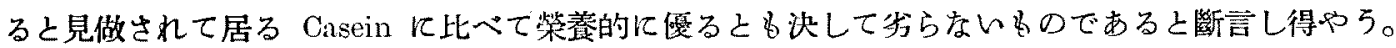

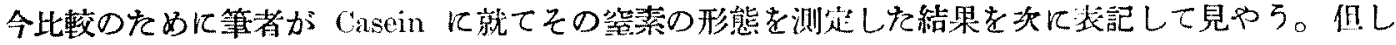
供試した Casein は動物繘育用のために酒精を胕ひて再三洗湺乾燥したものである。

$$
\text { 第一表 }
$$

Forms of Nitrogen in Cow-milk Casein

\begin{tabular}{l|c|c|c}
\hline & In Original Casein & In water free Casein & $\begin{array}{c}\text { In the soluble in } \\
\text { HCl } N\end{array}$ \\
Water & $\% \%$ & $\%$ & $\%$ \\
Total- $N$ & 8.070 & 14.209 & \\
Insoluble in HCl $N$ & 13.063 & 0.07 & \\
Soluble in HCl $N$ & 0.072 & 14.191 & 100.00 \\
Ammonia- $N$ & 12.991 & 1.744 & 12.34 \\
Humine- $N$ & $1.60 \%$ & 0.144 & 1.02 \\
Total- $N$ in form of bases & 0.132 & 2.982 & 21.11 \\
Amino- $N$ in bases & 2.742 & 1.963 & 13.89 \\
Arginine- $N$ & 1.805 & 0.922 & 6.53 \\
Histidine- $N$ - & 0.848 & 0.491 & 3.47 \\
Lysine- $N$ & 0.451 & 1.551 & 10.98 \\
Cystine- $N$ & 1.426 & 0.018 & 0.13 \\
Total- $N$ in filtrate from bases & 0.017 & 9.074 & 64.21 \\
Amino- $N$ in non-bases & 8.342 & 8.542 & $60.4 \overline{0}$ \\
\hline
\end{tabular}




\section{C. 要 約}

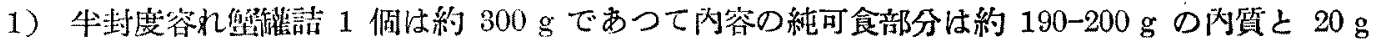
餘の汁液とである。

2) 肉及で汁液に就ての分析結果によつて汁液中には約 $1 \mathrm{~g}$ の蛋白が含まれ肉は殆んど全く蛋白 であることを知り得て壁肉の淡味なる所以を明らかにした。

3）肉蛋白中の空素の形態をVan Slyke 氏法に從つて定量した結果に揞りズワイカ二肉蛋白は Casein に比して策䖭上陵れて居ることを推斷した。

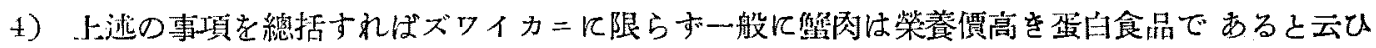
得る。

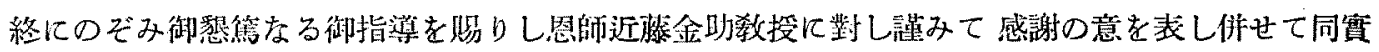
驗室の諸氏から多大の御助力を得たことを溜謝す。

文

㱆

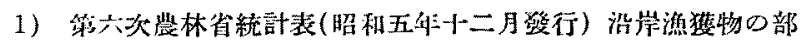

2) Yuzuru Okuda: J. Dept. Agriculture, Kınshu Imp. Univ., Vol. 1 (1925) No. 4.

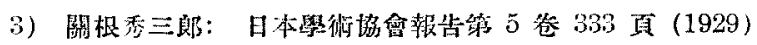

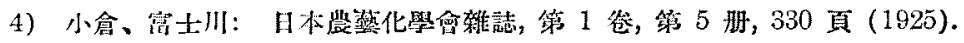

（1981 年11月18 日、宗都帝大、化學研究所、奈艮女子高等所範學校)

\section{馬鈴暮の有機鹽基特にカダベリンの存在に就て}

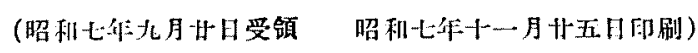

吉忖清向岩田武志

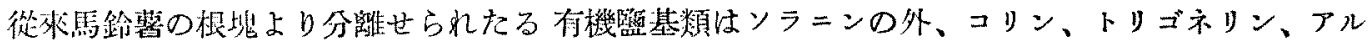

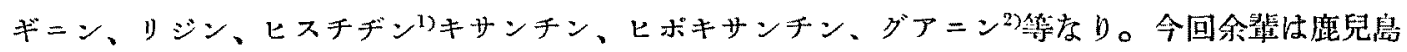

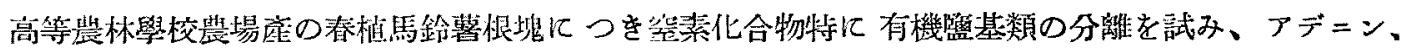
ヒスチヂン、アルギニン、トリゴネリン、コリン、カダベリン等の存在を確め得劣り。而して茲に 特筆すべをカダベリンの你在なりとす。盖しカダべリンは蛋白質の組成分の一たるリジンの分解

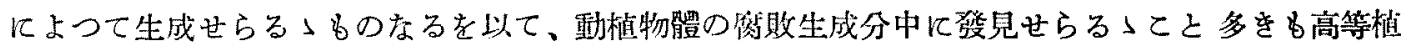

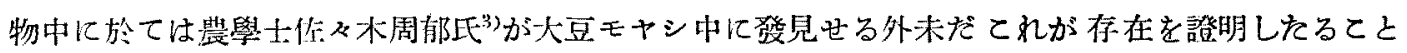

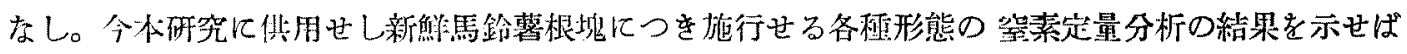
次の如し。

\begin{tabular}{|c|c|c|c|}
\hline 水分 & $.61 \% \%$ & $33 \%$ & \\
\hline & 新鮮物 100 分中 & 乾物 100 分币 & 企羑素を 100 として \\
\hline 全筑軎 & 0.317 & 1.416 & 100.0 \\
\hline 蛋白筫窒琹 & 0.204 & 0.913 & 64.5 \\
\hline 非蛋白颀埕素 & 0.113 & 0.503 & 35.5 \\
\hline \multirow{3}{*}{ 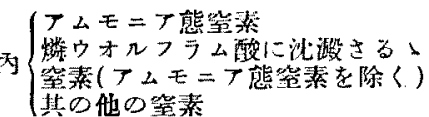 } & 0.004 & 0.017 & 1.2 \\
\hline & 0.038 & 0.170 & 12.0 \\
\hline & 0.071 & 0.316 & 22.3 \\
\hline
\end{tabular}

1) E. Schulze: Landw. Versuchst, 59 (1904), $331 . \quad$ 2) E. Schulze und Bosshard: Z. physiol.

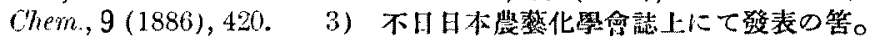

